\title{
Perception and Production of Consonants of English by Pakistani Speakers
}

\author{
Nasir Abbas Syed ${ }^{1}$, Sanaullah Ansari ${ }^{2} \&$ Illahi Bux Gopang ${ }^{2}$ \\ ${ }^{1}$ Lasbela University of Agriculture, Water \& Marine Sciences, Baluchistan, Pakistan \\ ${ }^{2}$ Institute of English Language \& Literature, University of Sindh, Pakistan \\ Correspondence: Illahi Bux Gopang, Faculty of English Language \& Literature, Lasbela University, Baluchistan, \\ Pakistan. E-mail: illahi_gopang1234@yahoo.com
}

Received: November 29, 2016 Accepted: January 3, 2017 Online Published: March 16, 2017

doi:10.5539/ijel.v7n3p201

URL: http://doi.org/10.5539/ijel.v7n3p201

\begin{abstract}
This paper depicts a comprehensive picture of consonants of Pakistani English (PakE). The study shows that PakE speakers neutralize aspiration contrast in English stops. In the PakE, /t/ in /st/ cluster on onset of a word (e.g., steal) is produced with more aspiration than that on syllable-initial position without preceding /s/ (e.g., in "teach"). Besides, /t d/ are produced with strong retroflexion but /t/ in tautosyllabic/st/ clusters on word-initial position is produced without retroflexion. Voiced stops are produced with pre-voicing. Dental fricatives $/ \theta \partial /$ produced by native speakers of English are perceived as [ $\mathrm{f}]$ or $[\mathrm{s} \mathrm{v}]$ by PakE speakers but they produce these fricatives as stop. PakE speakers can realize a difference between clear and dark lateral of English in perception although they do not maintain the same difference in production as they produce English lateral as a clear lateral on onset and coda of syllables. Coronal fricative $/ 3 /$ is perceived and produced as approximant $/ \mathrm{j} / \mathrm{and} / \mathrm{v} \mathrm{w} /$ as a labial approximant. In PakE [r] is produced with strong trilling and rhoticity on all word-positions.
\end{abstract}

Keywords: British English, consonants, Pakistani English, perception, production

\section{Introduction}

English is a language which is spreading world-wide. It has transplanted varieties like those spoken in Pakistan, India, Africa and other countries which have been part of the British Empire in the past. In these countries, the arrival of English language dates back to the days of colonial era. A lot of literature is available on Indian English but there is not much literature on Pakistani English (PakE). Some studies analyzed Indian English produced by Hindi/Urdu speakers of Northern India e.g., those by Asrani, (1964) and Sisson (1971). The generalizations developed about Hindi speakers may also be true for Urdu speakers because Hindi and Urdu are dialects of the same origin (Rahman, 2011). Among the very rare available studies on PakE, Usmani (1965) only focuses on stress pattern of Pakistani English. Rahman (1991), Mahboob \& Ahmar (2004) and Afsar \& Kamran (2011) are the only available studies which analyze consonants of Pakistani English in some detail. However, some features of consonants of PakE have not been described in the previous studies at all. The current study is a step forward in this regard. It particularly highlights those aspects of the PakE which have not been already described in the previous studies. In the following section, findings of the previous studies on Pakistani English are briefly described. A brief description of the previous studies summarized below clearly indicates that a detailed description of the PakE, based on empirical evidence is utterly required.

\section{Review of Previous Studies on PakE}

Rahman (1991) divides Pakistani speakers of English into four classes and considers their English as different dialects (sociolects) on the basis of social stratification. Although he differentiates between these varieties to some extent, but in this section we shall summarize only common features of the PakE found in all varieties defined by Rahman (1991). He briefly describes both segmental and supra-segmental features in his study. In the segmental features, Rahman (ibid) discusses both vowels and consonants. The study is based on an analysis of production of English words by Pakistanis who speak Urdu, Punjabi and Pashtu. According to Rahman, Pakistani speakers produce British English dental fricatives $[\theta \partial]$ as dental stops $/ \mathrm{t}_{n}^{\mathrm{h}} \mathrm{d} /$. However, Pashtu speakers produce voiceless dental fricative as voiceless unaspirated stop $/ \mathrm{t} / \mathrm{t}$. The reason for this may be absence of aspirated stops in the phonemic inventory of Pashtu (Syed, 2011). Another important feature of the PakE is that it does not have aspiration contrast in obstruent plosives. In British English, on stressed position, normally 
voiceless stops are produced with aspiration and in unstressed contexts, they are produced as unaspirated stops (Davenport \& Hannahs, 2010). The PakE has only voiceless unaspirated stops in all positions. Rahman ascribes this to Pakistani languages and English orthography. English orthography does not reflect this allophonic variance. Therefore, Pakistani speakers who in the absence of native speaker model in front of them while learning English, depend on orthography in English pronunciation and do not maintain allophonic variance in aspiration for English obstruent stops. Rahman (1991) also ascribes this to Pakistani languages. In Pakistani languages like Urdu, Saraiki, Punjabi, Sindhi, Kashmiri, etc. aspiration contrast is phonemic. Therefore, for Pakistanis, substitution of an aspirated sound with an unaspirated one or vice versa, means change of one word with the other. A scientific reason that Rahman gives for this phenomenon is that since in Pakistani languages, the aspiration contrast is phonemic, thus, there is a wider categorical difference of voice onset time (VOT) for aspirated and unaspirated plosives in Pakistani languages. On the other hand, since in English this contrast is allophonic, the difference of VOT ranges of aspirated and unaspirated obstruent stops is too small that sometimes both overlap. Thus, PakE speakers cannot perceive a difference between aspirated and unaspirated stops of British English.

According to Rahman (1991), PakE speakers produce BE alveolar stops /t d/ as retroflex consonants /t d/. In his opinion, $/ 1 /$ and $/ \mathrm{r} /$ are also produced as retroflex. Besides, the allophonic variance between dark and clear lateral, which exists in BE, is not maintained in the PakE. In BE, lateral /1/ is produced velarized on coda of a syllable but it is produced a clear lateral on onset position (Roca \& Johnson, 2007). The PakE does not maintain such allophonic variance. In the PakE, lateral $/ 1 /$ is produced without velarisation on all positions. $/ \mathrm{v} / \mathrm{and} / \mathrm{w} /$ are assimilated in the PakE. According to Rahman (1991), in Pakistan, Urdu speakers add a vowel word-initially if the words start with "st, sk, sp" clusters but Punjabi speakers add an epenthetic schwa between the consonants to break the clusters. Pashtu speakers do not break such clusters because such clusters also exist in Pashtu. According to Rahman (ibid), anglicized and upper class varieties of PakE are closer to RP but those of graduates of lower class educational institutions are far from the RP. (Let us keep in mind that English is a phenomenon of only educated class of Pakistan society as it is taught formally in educational institutions of Pakistan). However, Rahman does not clearly define how he demarcated these varieties. He also does not mention how many speakers were selected in his study from each variety of the PakE and each L1 under study and which analysis techniques were used in reaching these generalizations.

Mahboob \& Ahmar (2004) did another attempt to define consonants of Pakistani English spoken by those speakers whose mother tongue is Urdu. They give a very brief introduction of how English developed in the Sub-continent of Pakistan and India. The authors agree with Kachru (1992) that because of absence of native input, English developed its indigenous character in South Asia. The study is based on analysis of speech of six (four male and two female) Pakistani speakers of English whose mother tongue was Urdu and whose ages ranged between 22 and 37 years. The authors do not give details of data collection techniques or paradigms which they adopted in analysis of productions of their subjects. In the findings section, they give a brief introduction of vowels of the PakE. They also point out pronunciation differences between PakE and BE speakers which emerged because of orthography. For example, Pakistani speakers geminate consonants $/ t /$ and $/ \mathrm{p} /$ in English words like "letter" and "happy" because of spellings. The phenomena of vowel epenthesis in consonant clusters and some prosodic features of the PE are also discussed by Ahmar \& Mahboob (ibid).

Mahboob \& Ahmar (2004) also point out that Pakistani learners of English do not maintain allophonic variance in English laterals. The authors ascribed it to the L1 of their participants. Urdu does not have allophonic variance in laterals and native speakers of Urdu produce their L1 lateral /1/ clearly on all positions. According to Mahboob \& Ahmar (ibid), the same practice is transferred in the PakE spoken by Pakistanis who speak Urdu as the L1. They also do not differentiate between English / $/ \mathrm{k}$ and /w/ and according to Mahboob \& Ahmar (ibid), they produce variants of $/ \mathrm{w} /$ for these two consonants (p. 1011). The authors also ascribed this to the L1 of the speakers. Urdu does not have two such consonants on labial position (i.e., [v w]). According to the findings of Mahboob \& Ahmar, Pakistani speakers do not maintain aspiration contrast on different positions. According to the authors, this is also because the aspiration contrast is phonemic in Urdu and is represented in Urdu orthography. On the other hand, the allophonic variance of aspirated and unaspirated voiceless stops is not reflected in English orthography. Thus, Pakistani Urdu speakers of English produce English voiceless stops without aspiration in all positions. They also found that unlike BE speakers, PakE speakers produce English /r/ as a rhotic and $/ \mathrm{t} \mathrm{d} /$ as retroflex. BE speakers produce $[\mathrm{r}]$ without rhoticity, and if it occurs syllable-finally, it is produced as a vowel. According to Mahboob \& Ahmar, English dental fricatives are produced as dental stops $\left[\mathrm{t}^{\mathrm{h}}\right.$ d] in the PakE. Like Rahman (1991), Mahboob \& Ahmar (2004) also do not explain the paradigms used in the analysis of phonemes of PakE. 
Afsar \& Kamran (2011) also compared consonants of what they call Standard British English (SBE) with those of the Standard Pakistani English (SPE). They recorded 178 productions of 20 M.Phil/PhD students (ten male and ten female) aged 27-40 years. All participants of their study were MA English degree holders from Pakistan and were also teaching English at a university in Islamabad. These participants also speak different languages of Pakistan as L1s; therefore, according to the claim of the researchers, their findings are true generalizations about what they call Standard Pakistani English. The authors also claim that because of their advanced standard of learning, their English speech was free of the L1 interference. The study claims to have adopted advanced technology in data analysis but no details of methodology are clearly mentioned.

According to the findings of Afsar \& Kamran (2011), Pakistani speakers use a labio-dental approximant $/ v /$ instead of $/ \mathrm{w} /$ in their English speech. A major difference between these findings and those of the earlier studies is that the previous studies claim that the PakE has a single phoneme for two British English phonemes /v w/, but Afsar and Kamran find that in the Standard Pakistani English, $/ \mathrm{v} /$ and $/ \mathrm{v} /$ are two different phonemes corresponding to British English $/ \mathrm{v} /$ and $/ \mathrm{w} /$, respectively. Like the previous studies, aspiration contrast is found to be non-existent in the Pakistani English and the same reasons have been given by Afsar \& Kamran as already mentioned by Rahman (1991). Another similarity between this study and the previous ones is that the latter also confirms that the Pakistani speakers do not maintain allophonic variance between clear and dark lateral of English. Dental fricatives are produced as dental stops by the participants of this study (i.e., Afsar \& Kamran, 2011). They also claim that Pakistanis substitute voiceless dental fricative of British English with voiceless aspirated stops. Unlike Mahboob \& Ahmar, the participants of Afsar \& Kamran break "sp, st, sk" clusters by inserting a schwa between, rather than before, the consonant clusters. /r/ was found rhotic and sometimes with retroflexion in this study. A very significant finding of the study by Afsar \& Kamran is that their participants produce English affricates and alveo-palatal fricatives with a frication duration which is shorter than that produced by native speakers of British English. Another important finding of this study is that most of the Pakistani speakers of English substitute palato-alveolar fricative [3] with [j]. According to Afsar \& Kamran, consonants written with double letters were produced geminated by their participants. The approximant [j] was found missing in the pronunciation of such words as "student, stupid" etc. Thus, the study by Afsar \& Kamran is an advancement in the existing literature on the PakE. It unearthed some aspects of Pakistani English which were not discussed in the previous literature.

Pakistan is a multi-lingual country with more than sixty languages being spoken in the country (Rahman, 1996). These languages are from three different families namely, Indo-Aryan, Iranian and Dravidian. It is really important but difficult to study the true nature of English spoken by these peoples. The previous studies could not encompass all aspects of consonants of the PakE. Besides, the major question mark against these studies is that if their participants really make a true representative sample of all Pakistani speakers of English who speak more than sixty different L1s and each L1 influences its speakers' English in different ways.

The current study uses phonetic data analysis techniques and presents a feature-based phonological analysis of consonants of PakE. Out of many models of feature geometry e.g., Chomsky \& Halle (1968), McCarthy (1988), Sagey (1986), Rice \& Avery (1993), Clements (1985), Clements \& Hume (1995), etc. we shall depend on Clements \& Hume (1995) model which is applied most commonly in the current literature on phonology. Importantly, the previous studies are based on production only. The current study is based on perception as well as production of consonants of English by speakers in Pakistan. In the last quarter of the previous century, the attention of researchers shifted from production to perception (Best, 1995; Best \& Tyler, 2007; Brown, 1998, 2000; Flege, 1995; Iverson \& Kuhl, 1995; Kuhl, 1994; Kuhl et al., 2008). In the current literature on second language learning, perception is considered equally or more important than production because learning a language starts with perception.

The current paper presents a precise but comprehensive picture of consonants of the PakE. The current study is different from the previous studies because of its larger sample (70 participants from Pakistan and 22 native speakers of English from England), control of L1 influence, use of acoustic analysis of data, study of some consonants which were neglected in the previous studies and application of statistical data analysis tests. The following section notes main objectives of the current study.

\subsection{Objectives of the Study}

This research was conducted with a view to obtain the following objects;

a). To study, analyze and describe consonants of PakE

b). To compare production and perception of consonants of English by Pakistanis 
c). To highlight the difference between British English and PakE in production and perception of consonants

To achieve these objectives a large scale data was collected for analysis. In the following section a detail on the research methodology adopted in this study is given.

\section{Research Methodology}

\subsection{Target Consonants}

In this study, only those consonants have been selected for discussion which are produced differently in Pakistani English (PakE) and British English (BE). In the words of Flege (1995), it is extremely rare to find two identical sounds in two different languages. There are always some phonetic differences between even corresponding sounds of two different languages. However, the current study focuses on only those consonants which are clearly and solidly different in the PakE and BE. Specifically, the consonants which are under discussion in this paper are obstruent plosives $/ \mathrm{p} \mathrm{b} \mathrm{t} \mathrm{d} \mathrm{k} \mathrm{g/,} \mathrm{fricatives} / \theta \partial_{3} \mathrm{v} /$, affricates $/ \mathrm{f} \mathrm{d} /$ and approximants $/ 1 \mathrm{rw} /$.

\subsection{Samples of the Study}

The findings of the current study are based on perception and production experiment with 70 Pakistani speakers of English who were all graduates of Pakistani Universities. These participants will be called target group in the later discussion. 22 native speakers of British English in England also participated in this study as a control group for comparison of native BE pronunciation with that of Pakistan group. They will be referred to as control group in the later discussion. The native speakers who participated in this study claimed that they speak Southern British English and they had no speaking/hearing difficulties. The target group were all graduates from Pakistan and they all speak Saraiki as the L1. They all had either studied or were teaching in public sector institutions of Southern Punjab where Saraiki is a dominant language. The age of the target participants (learners group) ranged between 23 and 51 years (mean=32.66 SD=7.8). Having a look at the consonant phonemic inventory of Saraiki (Shackle, 1976, p. 18), it becomes clear that with a few minor exceptions, all consonants of languages of Pakistan are also found in Saraiki. Saraiki is an Indo-Aryan language and has all consonants in its phonemic inventory which other languages of the same family have. Thus it is assumed that the samples of this study represent more than 75\% population of Pakistan as speakers of Indo-Aryan languages in Pakistan make more than $75 \%$ of the total population of the country (Ali, 1993).

\subsection{Stimuli}

In production test, words written on a piece of paper were given to the participants who were asked to produce these words in accurate English with as natural way as they possibly could. The list of stimuli had the words carrying target sounds. The list included the words "peak, speak, teach, steal, key, ski, deal, beak, geese, read, league, weed, Venus, measure, thief, these, cheat, jeep" and some distractors. Each target word was written in the list three times randomly. The context factor was strictly controlled in selection of the stimuli. In all except one stimuli, the target consonants were on word/syllable initial position and were immediately followed by the same tense high front vowel of English so that the effect of adjacent vowel on production of consonants is neutralized or at least equalized for all target consonants. All except two stimuli were of monosyllabic words. Only the words "measure" and "Venus" which studied the production of alveo-palatal fricative $/ 3 /$ and labial fricative $/ \mathrm{v} /$ were different from other stimuli as they were not monosyllabic and the former did not have the target consonant on word-initial position. The reason for this was that we could not find a commonly used monosyllabic word of English which starts with $/ 3 /$ and $/ \mathrm{v} /$ and is immediately followed by a high front tense vowel. Initially we started with the French loanword "gite" but the participants were not familiar of this word so they could not yield natural productions of this word/consonant on account of their being unfamiliar with the stimulus. Thus, the word "gite" was replaced with a more commonly known frequently occurring word "measure" in the list of stimuli. The word "Venus" used as a stimulus to elicit production of $/ \mathrm{v} /$ by the participants was also not monosyllabic although the target consonant $/ \mathrm{v} /$ was on word-initial position. The reason for this is also the same, i.e., we could not find a commonly used monosyllabic word of English starting with $/ \mathrm{v} /$ immediately followed by high front tense English vowel.

Perception test stimuli were meaningless nonce words of VCV structure carrying a target consonant of English on $\mathrm{C}$ position flanked by low vowel /a/ on both sides. Meaningless nonce words were used for perception test stimuli to control the effect of word-familiarity in perception test. If we had used meaningful words, there was a probability that the participants could guess the nature of target consonant on account of context. The reason that low vowel was used in perception test stimuli is that our pilot study confirmed that only /a/ vowel has neutral effect on perception whereas other vowels have varying significant effect on perception. In the same pilot study, 
effect of vowel on production was also tested. The results show that vowel effect on production was over all neutral. Thus, for production test stimuli high front vowel was used because monosyllabic English words of common use starting with the target consonants immediately followed by a high front tense vowel were easily available whereas we could not find suitable stimuli for all target consonants in the words on initial position immediately followed by low vowel. That is why high front vowel was preferred for production test but low vowel for perception test stimuli.

VCV type of stimuli spoken in the voice of a native speaker of English who was herself a student of PhD in Phonetics and speaks Southern British English produced these stimuli. She was asked to produce the stimuli in standard British English. Four native speakers of the same area later on listened the stimuli and confirmed that those stimuli were produced in natural accurate standard British English accent. Three repetitions of each stimulus were used in perception (identification) test. Some distractors were also included in the list of perception test stimuli. Perception test was conducted with four native speakers for confirmation of the stimuli only and with the target group. But production test was conducted with both Pakistan-based target group ( $\mathrm{N}=70)$ and native speakers control group $(\mathrm{N}=22)$. A discrimination test was also conducted with the target group only which carried the same VCV stimuli consisting of pairs of confusing consonants of English or L1 and L2 like /v/ and /w/ of English or English /d/ and L1 retroflex /d/. Some distractors were also included in the discrimination test. The pairs of consonants were played and the listeners were asked to determine if they heard the same or two different consonants in the stimuli. The stimuli for this test were also recorded in the voice native speakers of both language and were similarly validated by four native speakers of each language (English and Saraiki) before using in the test.

\subsection{Data Collection and Analysis Techniques}

Perception and production of the participants were tested in this study. Since there were three repetitions of each stimulus of perception test, one mark was awarded on one correct perception. Thus the marks of perception test ranged between zero and three. Perception test was conducted with the control group only and with four native speakers of English for the purpose of verification of the stimuli.

Production test was conducted with both groups. The recordings of the production test were first evaluated by four native speakers of southern British English who were living in Essex. The reliability of evaluation was determined by using Cronbach's alpha reliability test. Only those results were taken for analysis which had a cut-off point of 0.7 alpha value (which is a standard for excellent reliability (Larson-Hall, 2016)) in the reliability test. English native speaker judges evaluated productions of English consonants produced by Pakistani learners on a five point Likert Scale ranging between one and five. On the scale five meant "quite native-like production" four "slightly deflected away from native speakers", three "different from native speakers of British English but understandable" two "hard to understand for a British native speaker" and one meant "not understandable as the target consonant of British English". The judges compared the productions of participants with standard British English considering BE as the yardstick. Only productions of Pakistan-based participants (target participants) were evaluated by English native speakers. Productions of native speakers (control) group were not evaluated by native speaker judges. However, productions of Native speakers (control group) were evaluated at acoustic analysis stage for comparison with productions of the target group.

Later on, the production test recordings of both groups i.e., target participants and control group, were also analyzed acoustically using Praat (Boersma \& Weenink, 2012) for further confirmation of the results obtained in British English native speakers' evaluation. Presence and absence of aspiration in voiceless stops were evaluated by getting voice onset time (VOT); presence and absence of lip-rounding in $/ \mathrm{v} w /$ was determined on frequency of third formant of adjacent vowels and retroflexion in $/ \mathrm{t} d /$ were also determined by getting frequency of third formant of vowels adjacent to $/ \mathrm{t} d /$ in the productions of the target participants. Difference between stops and fricatives/affricates was determined on the basis of whether there was silence duration for stops or turbulent fricative noise on the relevant part of spectrograms. Readings obtained in productions of the target group and native speakers were analyzed using inferential statistics to determine similarity and/or difference between productions of both groups.

Multiple statistical analyses were conducted to reach solid conclusion. Reliability of data was determined on the basis of a Cronbach's alpha reliability test and sampling errors were identified by running parametric and non-parametric analyses depending on distribution of the data. The normal distribution was determined on the basis of one sample KS test. Generalizations based on these analyses are given in the following section.

\section{The Consonants of PakE}

Various types of consonants of PakE are briefly defined in the following subsections. Only those consonants 
which are either not already studied by previous researchers or are found to be different from the previous findings, are discussed with some detail. Those consonants which are found to be exactly the same as in the previous research, are mentioned without any further comment or discussion.

\subsection{The Voiceless Plosives / $t \mathrm{k} /$}

British English voiceless obstruent plosives are aspirated word initially and in the onset of a stressed syllable but unaspirated in unstressed syllable, after "s" (e.g., speak, ski, steal, etc.) or on coda positions. Thus, aspiration contrast is basically allophonic in English. The results of the current study confirm those of the previous studies that obstruent stops are produced only unaspirated by Pakistani speakers in all contexts. According to native evaluation conducted in the current study, these consonants are produced by Pakistanis as "near native-like" or sometimes as "different from natives but understandable" but not "native-like" at all. Voice onset time for plosives were taken as acoustic cues for aspiration. Voice onset time is the interval between burst of a stop and the onset of the periodic noise of vocal folds. Normally, it is claimed that Lisker \& Abramson (1964) formally introduced this term for systematic analysis of plosives. A study of voice onset time for plosives produced by Pakistanis shows that velar stop $/ \mathrm{k} /$ is more aspirated than labial and coronal stops. Therefore, Pakistanis can, in some cases, produce English velar $/ \mathrm{k} /$ with aspiration with relative ease. The reason for this is that a shorter distance between place of articulation and vocal folds gives a bigger VOT. Besides, a wider area of contact between active and passive articulators also results in a longer VOT for stops. Thus, a shorter distance between point of articulation and vocal folds and a wider place of contact between active and passive articulators for velar stops are, due to articulatory and aerodynamic reasons, more conducive for production of an aspirated stop which, like other stops, is produced unaspirated by Pakistani speakers of English. Since normally Pakistanis produce English stops without aspiration, their problem is that they do not produce aspirated allophones of voiceless stops of English accurately. The above mentioned aerodynamic and articulatory factors can facilitate them in production of aspirated stops at velar place of articulation. In other words, if Pakistanis have to acquire British English aspiration contrast, they are expected to acquire aspiration contrast in velar stops first of all.

Phonologically, aspiration contrast is allophonic in English but phonemic in Pakistani languages. Thus, aspirated and unaspirated stops of English language are at complementary distribution with each other whereas they make minimal pairs in Pakistani languages. The problem that Pakistanis produce voiceless stops without aspiration in even stressed positions, arise mainly because of English orthography which does not maintain aspiration contrast in spelling. Pakistanis, in the absence of native speakers particularly after the departure of the native speakers of English in 1947, have been depending on written English for last seven decades; therefore, they could not maintain this aspiration contrast in their English. Later on, it became a norm in the PakE to neutralize aspiration contrast in English plosives. (Note 1) Now for a Pakistani, substitution of an unaspirated stop with an aspirated one is equal to changing a word with another. In the language of feature geometry, we can say that feature [spread glottis] is active in indigenous Pakistani languages but not in British English. Therefore, for Pakistanis, substitution of an unaspirated stop with an aspirated one is equal to changing a consonant which is [-spread glottis] with one of [+spread glottis]. (Note 2) Thus, they do not produce English obstruent stops with aspiration. Among voiceless stops, English coronal stop /t/ is also produced as retroflex. This phenomenon is discussed in the following sub-sections.

\subsection{The Voiced Plosives / $b$ d g/}

Languages of the world are divided into voicing and aspiration languages (Harris, 1994; Iverson \& Salmons, 1995). Languages like Arabic (Flege \& Port, 1981), Saraiki (Syed, 2013), Dutch (Simon, 2009, 2011), Spanish (Flege \& Eefting, 1988), Russian (Backley, 2011), Japanese (Shimizu, 2011), Hungarian (Lisker \& Abramson, 1964), etc. are considered voicing languages but German (Hamann, 2011), English (Honeybone, 2005), Swedish, Korean, Icelandic (Backley, 2011), etc. are aspiration languages. In voicing languages, voicing starts before the burst phase of an obstruent stop. This is also called pre-voicing or lead-voicing. In aspiration languages, vibration of vocal folds for voicing of the immediately following vowel starts normally after the burst phase; a phenomenon which is called post-burst voicing.

The English voiced stops of Pakistanis are strongly influenced by their L1s (Syed, 2013). Voiced stops are pre-voiced in almost all major Pakistani languages but they are produced with post-burst voicing in British English. The duration of pre-voicing of a voiced stop is in positive correlation with the distance between place of articulation and vocal folds e.g., /g/ being closet to the vocal folds has the shortest pre-voicing duration but /b/ being maximally distant from the vocal folds has the longest pre-voicing duration in the PakE. Under the influence of mother languages, Pakistanis produce voiced stops of English /b d g/ with pre-voicing. This is a prominent feature of the PakE which is already neglected by the previous researchers. A possible confusion 
arises in communication between PakE and BE speakers. BE speakers sometimes perceive words like "peak", "tale" or "keys" produced with word-initial stops having short-lag VOT by PakE speakers, as "beak", "dale" or "geese" respectively. Similarly, the words like "beak", "dale" or "geese" produced by native speakers of BE with short-lag positive VOT of initial stops, are sometimes perceived as "peak", "tale" or "keys" respectively by PakE speakers. BE native speakers produce voiced and voiceless unaspirated stops with almost equal VOT ranges (Docherty, 1992). They maintain a difference between voiced and voiceless unaspirated stops because of their complementary distribution of occurrence on word-initial position (Spencer, 1996). On coda position, they maintain a contrast between these two types of plosives by vowel lengthening before voiced stops (Flege, 1993). The PakE does not have such phonotactics. They rather have a categorical division of pre- and post-burst vocal fold vibration for voiced and voiceless stops respectively.

Another significant difference between PakE and BE plosives is that in BE coronal stops are alveolar which are produced without retroflexion but the same are produced with retroflexion on alveo-palatal zone in the speech of Pakistanis. Retroflexion in a consonant causes formant lowering of the adjacent vowels, particularly third formant of a vowel is significantly lowered if the immediately following consonant is produced with retroflexion. An acoustic analysis of productions of Pakistanis confirms that the third formant of vowels in their productions is significantly lowered if the vowel is immediately followed by a coronal stop $/ \mathrm{t} d /$. In terms of feature geometry, $\mathrm{BE} / \mathrm{t} /$ is [+anterior] because it is produced at alveolar ridge but the same is produced as [-anterior] in the PakE. By virtue of its articulation and frequency of occurrence, retroflex consonants are more marked than those produced without retroflexion (Hamann, 2003). But Pakistanis substitute English coronal with a retroflex consonant whereas they may also substitute it with a dental stop which also exists in all Pakistani languages. Since their dental place is already occupied by English dental fricatives, they do not substitute English alveolar stops with their L1 dental stops. See sub-section 5.3 below on dental fricatives in PakE for detailed description of this phenomenon.

Acoustic analyses further confirm that Pakistanis produce English / $/$ / in the words like "steal" without retroflexion. The third formant of the tense vowel in word "teach" produced by Pakistanis was significantly lowered but that in "steal" was not lowered compared with that of the native speakers of BE. This confirms that /t/ is produced as a retroflex in words like "teach" (where / $t /$ occurs on syllable-initiation position) but the same is produced without retroflexion in words like "steal" (where /t/ occurs after /s/ on syllable-initiation position in /st/ cluster). The reason for this is that both $/ \mathrm{s} /$ and $/ \mathrm{t} /$ are produced with two opposite articulatory gestures in PakE. /s/ is [+anterior] but in /t/ (which is actually produced as retroflex / $t /$ in PakE) is produced as [-anterior] (retroflex) in the PakE. PakE speakers cannot perform two opposite gestures simultaneously in production of English /st/ clusters which they actually produce as [st]. Consequently, they produce English /t/ without retroflexion (i.e., [+anterior]) in such a specific context (i.e., word/syllable initial "st" clusters) only. A very significant influence of retroflexion in English speech of Pakistani speakers/learners is that they produce $/ \mathrm{t} /$ in the words like "steal" (where /t/ occurs in /st/ cluster word-initially) with relatively longer VOT but that in words like "teach" with relatively shorter VOT. This is quite contrary to what native speakers of English do. The reason for this is that a stop produced with retroflexion has relatively shorter VOT than that produced without retroflexion. Since Pakistanis produce English / $t$ / with retroflexion, their VOT is shorter in such words where /t/ occurs on word-initial position but since the same consonant is produced without retroflexion in /st/ clusters, the same consonant has a relatively longer VOT.

\subsection{The Dental Fricatives / $\boldsymbol{\theta}$ d/}

Pakistani speakers produce English dental fricatives $/ \theta$ ð/ as stops (i.e., $\left[\mathrm{t}^{\mathrm{h}} \mathrm{d}\right]$ ). Thus the feature $[+$ continuant] in English dental fricatives is substituted with [-continuant] although feature [distributed] is faithfully retained in PakE. Acoustic analyses of production of participants of this study confirm that these consonants are produced as stop with exactly the same VOT as the L1 dental stops $/ \mathrm{t}^{\mathrm{h}} \mathrm{d} /($ Syed, 2013). English voiceless dental fricative $/ \theta /$ is produced as voiceless aspirated dental fricative but English voiced dental fricative / $ठ /$ is produced as a pre-voiced /d/. This is because of orthography of English which represents voiceless English dental fricative with the letters "th". The influence of orthography on phonology is well established in the literature (Hayes-Harb, Nicol, \& Barker, 2010; LaCharite \& Paradis, 2005). Under the influence of Pakistani languages, English / $/$ is produced with pre-voicing. Thus, although the feature [voice] of BE is retained faithfully in PakE, but the phonetic realization of this feature in the PakE is L1-like (i.e., with pre-voicing or negative VOT) which is utterly different from that of BE. The following spectrogram of the word "these" produced by a Pakistani speaker illustrates this fact; 


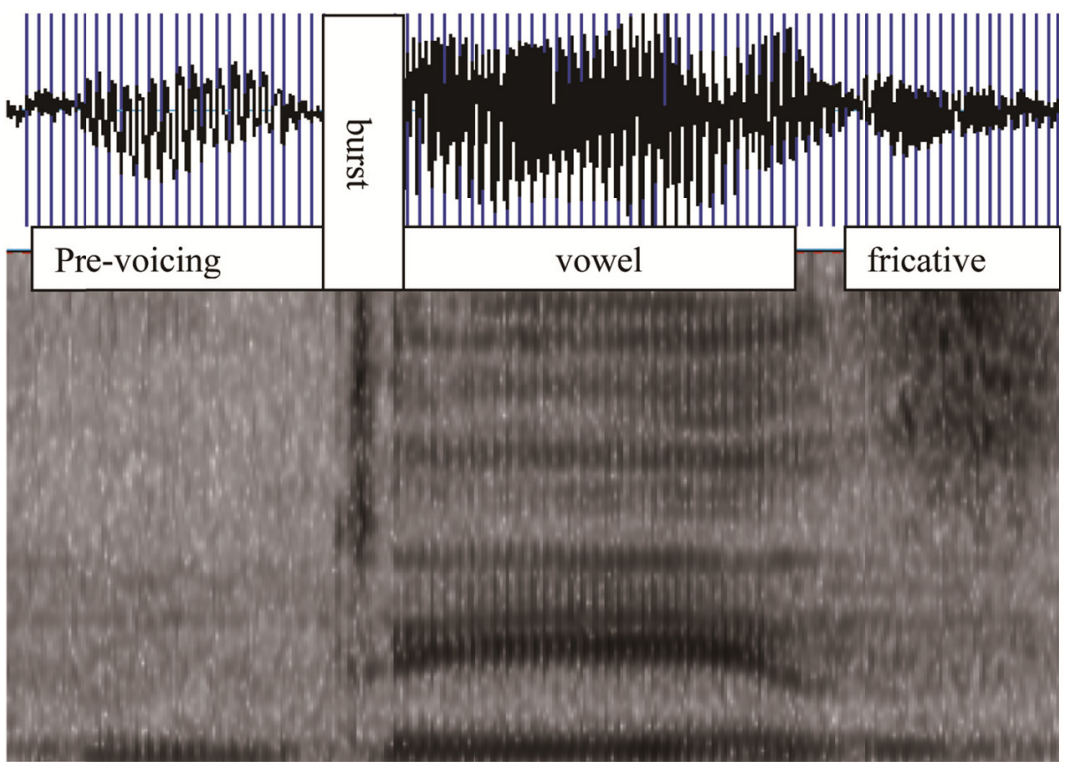

Figure1. Spectrogram of the word "these" produced by a participant

An important asymmetry between perception and production of English dental fricatives was observed in that, in production of Pak English words, these sounds are stops but in phonetic perception, these consonants of BE are perceived as fricatives by Pakistanis. They perceive $/ \theta /$ produced by native speakers of BE mostly as /f/ and sometimes as /s/. Similarly, /ð/ is perceived sometimes as /z/ but mostly as /v/ (Syed, 2013). This confirms that Pakistanis perceive these consonants on the basis of acoustic signals because labial $[\mathrm{f} v$ ] and coronal fricatives [s $\mathrm{z}$ ] have similar acoustic signals as $/ \theta$ ठ/ (Wester, Gilbers, \& Lowie, 2007). Although Pakistanis perceive these consonants on account of phonetic signals, they produce these phonemes on the basis of their orthographic representation. The fricative consonants produced by Pakistani learners were rated as "different from native-like but understandable" or sometimes "near native-like" according to evaluation of native speaker judges.

\subsection{Alveo-palatal Fricative /3/}

This consonant occurs in only French loanwords of English. In major Pakistani languages this consonant does not exist. (Note 3) In perception and production, Pakistanis assimilate this sound with the approximant / $\mathrm{j} /$ (Syed, 2013). Previous studies on the PakE have not discussed this consonant in detail. The native speakers of English from the United Kingdom rated the production of this phoneme by Pakistani participants of the current study as "different from native-like" and "hard to understand". In terms of feature geometry, BE / $/ 3$ is [-sonorant, + strident] but its substitute in Pakistani English i.e., /j/ is [+sonorant, -strident]. Acoustic analysis confirms that, in production of this consonant, PakE speakers lose fricative noise and add sonority. The following spectrograms illustrate this.

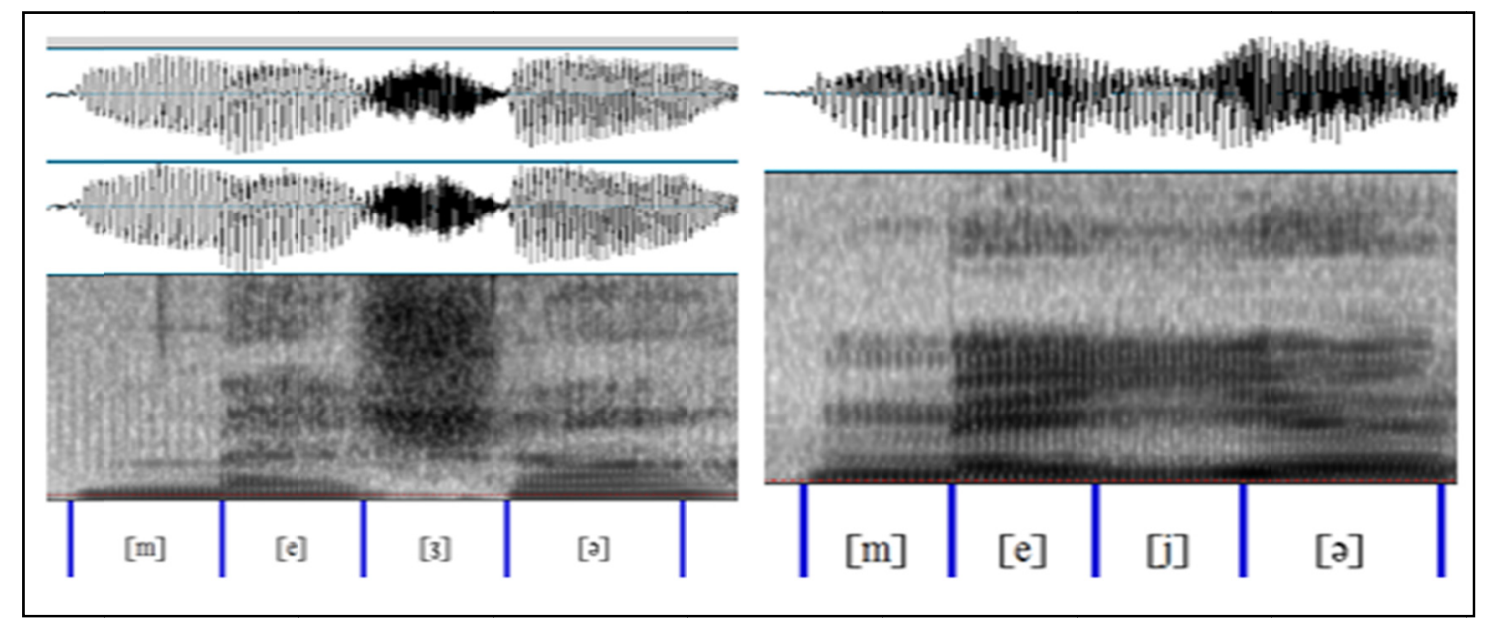

Figure 2. Spectrograms showing production of $/ 3 /$ by BE and PakE speakers 
The left part of figure 2, contains a spectrogram of the English word "measure" produced by a native speaker of British English living in the suburbs of London (a participant of the control group) and that in the right is produced by a PakE speaker (Pakistan-based participant). Fricative noise is quite apparent on the left spectrogram which is missing in the right spectrogram. Rather the right spectrogram reflects an approximant gesture on the onset of the second syllable. These acoustic indications on the spectrograms confirm that the word is produced as a fricative by the British native speakers but an approximant by PakE speakers.

\subsection{The English Labials / $v$ /}

According to the findings of the previous studies, PakE speakers assimilate $/ \mathrm{v} /$ and $/ \mathrm{w} /$ consonants. The current study also confirms that PakE speakers cannot differentiate between $/ \mathrm{v} /$ and $/ \mathrm{w} /$ in perception and production. This is because of the influence of L1s of PakE speakers. A look at consonant phonemic inventory of major Pakistani languages, like Punjabi (Shackle, 2007), Sindhi (Khubchandani, 2007), Saraiki (Syed, 2013), Urdu (Schmidt, 2007), Balochi (Elfenbein, 1997), Pashto (Elfenbein, 1997), Kashmiri (Koul, 2007), etc. shows that corresponding to English / v w/ consonants, Pakistani languages have a single approximant. Under the influence of Pakistani languages, PakE has developed a single approximant for these two consonants of the BE. In perception, PakE speakers cannot differentiate between these two consonants and produce a single approximant which lacks frication of $/ \mathrm{v} /$ and lip rounding of $/ \mathrm{w} /$. On the other hand, native speakers of BE perceive $/ \mathrm{v} / \mathrm{and} / \mathrm{w} /$ produced by PakE speakers as "hard to understand" and "different from natives". In the language of feature geometry, British English /w/ is [+sonorant, +round] and / $/$ is [-sonorant, -round]. The corresponding consonant in the PakE is [+sonorant, -round]. It lacks lip-rounding feature of $/ \mathrm{w} /$ and fricative noise of $/ \mathrm{v} /$. Acoustic analysis of production of PakE speakers confirms this. The following spectrogram shows a difference in the production of $/ \mathrm{v} /$ by PakE and BE speakers.
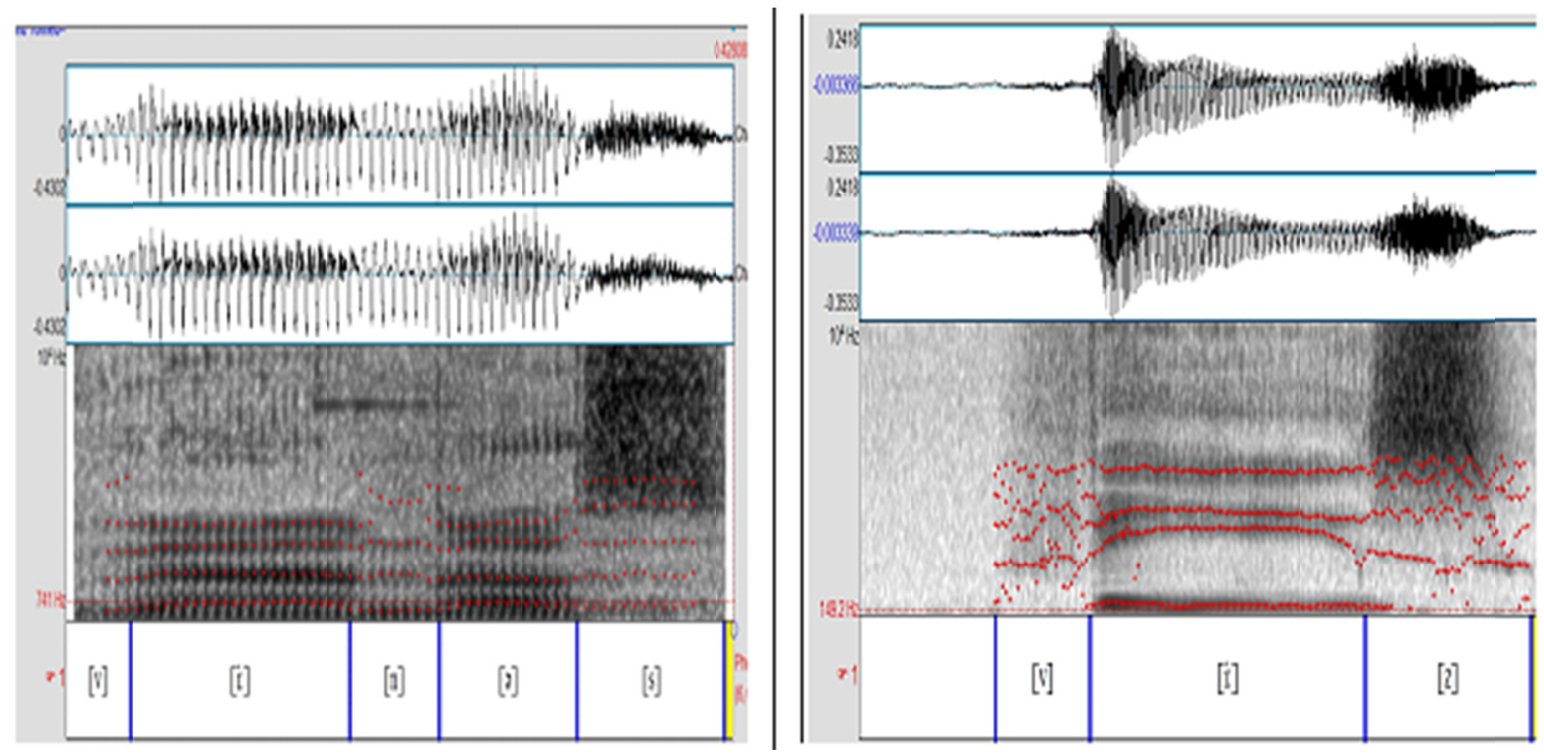

Figure 3. Spectrograms showing production of [v] by PE and BE speakers

Figure 3 contains in the left part a spectrogram of the word "Venus" produced by a PakE speaker and in the right is production of "V's" [viz] by a BE speaker. A turbulent noise on upper half of the spectrogram is an indication of frication (Ladefoged \& Maddieson, 1996). On word-initial position, a fricative noise is apparent on the upper part of the right spectrogram which is missing in the left one. This confirms that PakE speakers do not produce $/ \mathrm{v} /$ with frication.

$/ \mathrm{w} /$ is produced with lip rounding in the BE. In the current study, productions of PakE speakers were also analyzed acoustically. Lowering of third formant (F3) is an acoustic correlate of lip-rounding (Hamann, 2005). The analysis confirms that PakE speakers do not produce /w/ with lip rounding because no F3 lowering was seen in the productions of the participants from Pakistan. The findings of this study regarding $/ \mathrm{v} \mathrm{w} /$ are in line with those of the previous studies. 


\subsection{The English Liquids / $r$ /}

In British English, lateral phoneme /1/ has two different variants. On onset of a syllable, it is produced as a clear lateral [1] but on coda position it is produced as a dark lateral [1] by BE native speakers (Davenport \& Hannahs, 2010). The dark variant is produced with back of the tongue whereas the clear lateral is produced with tip of the tongue. In terms of feature geometry, English clear [1] is [+anterior, -high, -back], whereas English dark [1] is [-anterior, +high, +back] (Clements \& Hume, 1995). The previous research shows that PakE speakers do not maintain allophonic variance between dark and clear lateral. They produce /1/ as clear lateral in both positions. The findings of the current study are exactly the same as those of the previous studies. The subjects of this study produce $/ 1 /$ as clear lateral on onset and coda positions. However, they can perceive a difference between clear and dark lateral which means it may be relatively easier for PakE speakers to acquire allophonic variance in laterals. According to the evaluation of native BE speakers, PakE lateral on onset is near native-like but that on coda position is "different from native speakers but understandable".

The previous research shows that Pakistani speakers do not produce English / $\mathrm{r} /$ in a native-like manner. Native speakers of English particularly those of BE, produce / $r$ on syllable-initial position with a single touch of tongue to the passive articulator but Pakistanis produce it as a rolled or trilled consonant. The findings of the current study are also not different from those of the previous ones. According to the findings of this study, Pakistanis can discriminate English / $\mathrm{r}$ / from other consonants of English and no perceptual assimilation of this consonant with any other consonant of English was observed in the current study. However, PakE speakers have developed a phonetic category for English /r/ which is similar to that of their L1/r/. In most Pakistani languages /r/ is a rhotic produced with strong trilling. The same representation they have also developed for English $/ \mathrm{r} /$. The results of our experiment show that PakE speakers cannot perceptually discriminate between English and L1/r/ although there are solid phonetic differences between the two. Another important finding in this regard is that Pakistanis who speak Saraiki as L1, sometimes add a schwa-like vowel before /r/ word-initially (Syed, 2013). Thus, a word like "read" is produced as "aread" in the PakE by speakers of Saraiki. (Note 4)

\subsection{Other Consonants: Affricates, Velar Nasal and Laryngeal Fricative (Note 5)}

Corresponding to English affricates, Saraiki has obstruent plosives (Shackle, 1976). The results of the current experiments show that although PakE speakers can perceive English affricates and discriminate them from other sounds but they produce them as stops (Syed, 2013). They can even not perceive a difference between English affricates produced by native speakers of English and the corresponding PakE consonants produced as stops by PakE speakers. Thus a strong equivalence classification between BE affricates and PakE corresponding obstruent stops exists in the consonant inventory of speakers of PakE which cannot easily allow PakE speakers to realize the subtle phonetic difference between the two realizations of these consonants.

The consonants $/ \mathrm{h} /$ and $/ \mathrm{h} /$ were not part of this experiment. However, in another unpublished study we have observed patterns of these consonants in the speech of Pakistanis. British English $/ \mathrm{h} /$ is a voiceless fricative. Corresponding to this, Saraiki has a voiced laryngeal fricative /h/. Those PakE speakers who speak Saraiki as the $\mathrm{L} 1$, also produce English $/ \mathrm{h} /$ as a voiced fricative $/ \mathrm{h} /$. This is a consequence of equivalence classification between the L1 and L2 consonant. English velar nasal $/ \mathfrak{y} /$ also presents an interesting picture. This consonant does exist in the consonant phonemic inventory of Saraiki, the L1 of target participants of this study. It seems that they cannot realize this consonant in English nasals and produce it as a combination of alveolar nasal and the following velar stop. Thus the words like "sing" and "pink" are produced and perceived by them as [sing] and [pink] respectively but not as [sij] and [pink]. Although it is expected that such a combination of alveolar nasal immediately followed by a velar stop will yield an output that will be phonetically realized as having a velar nasal as a result of regressive spreading of the place of articulation of the velar stops, but consciously, PakE speakers do not realize existence of a velar nasal in English. This is also an indication of influence of orthography as English does not have a separate letter for velar nasal. These two consonants i.e., $/ \mathrm{h} / \mathrm{hnd} / \mathrm{g} /$, however, need further investigation with a large number of participants from Pakistan.

\section{Summary of Findings and Conclusion}

This study presented a comprehensive picture of consonants of PakE based on scientific study of productions of Pakistani English. We can summarize the findings of this study in the following points;

i. Aspiration contrast is neutralized in PakE; thus, aspirated stops of British English are produced without aspiration in PakE.

ii. Voiced stops of English are produced with pre-voicing.

iii. $\quad B E[t d]$ are produced with retroflexion in PakE. 
iv. British English affricates are produced as stops in PakE.

v. Dental fricatives are also produced as dental stops; the voiceless dental fricative is produced as voiceless aspirated stop and voiced dental fricative is produced as pre-voiced dental stop.

vi. BE $[\mathrm{v} \mathrm{w}]$ are both equated with a labio-dental approximant in the PakE.

vii. Allophonic variance in lateral is not maintained; thus, $/ 1 /$ on syllable coda position which is produced dark in the BE, is produced as a clear [1] as well as on word/syllable-initial position.

viii. /r/ is produced as a rhotic with strong trilling on both onset and coda of syllables.

ix. English velar nasal is phonologically realized as a combination of alveolar nasal and velar stop and voiceless $/ \mathrm{h} /$ is produced as voiced by some Pakistanis.

In the following table we present a consonant phonemic inventory of PakE. Along with consonants of PakE, the corresponding consonants of British English are also given in straight brackets to indicate which consonants of $\mathrm{BE}$ are substituted with which ones in the PakE.

Table 1. Consonant inventory of PakE

\begin{tabular}{|c|c|c|c|c|c|c|c|}
\hline 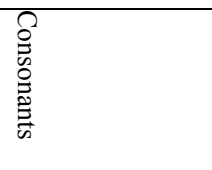 & 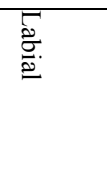 & 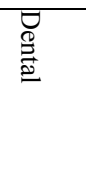 & 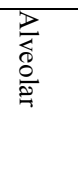 & 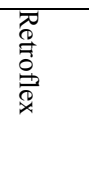 & 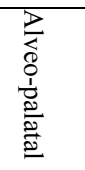 & 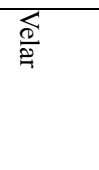 & 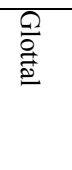 \\
\hline Stops: voiceless & $\mathrm{p}\left[\mathrm{p}^{\mathrm{h}} \mathrm{p}\right]$ & $\mathrm{t}_{n}^{\mathrm{h}}[\theta]$ & & $\mathrm{t}\left[\mathrm{t}^{\mathrm{h}} \mathrm{t}\right]$ & $\mathrm{c}[\mathrm{t}]$ & $\mathrm{k}\left[\mathrm{k}^{\mathrm{h}} \mathrm{k}\right]$ & \\
\hline $\begin{array}{l}\text { Pre-voiced } \\
\text { [voiced] }\end{array}$ & $\mathrm{b}[\mathrm{b}]$ & $\mathrm{d}[ð]$ & & $\mathrm{d}[\mathrm{d}]$ & $\mathrm{J}[\mathrm{d}]$ & $\mathrm{g}[\mathrm{g}]$ & \\
\hline $\begin{array}{l}\text { Fricatives: } \\
\text { voiceless } \\
\text { Fricative: Voiced }\end{array}$ & $\mathrm{f}[\mathrm{f}]$ & & $\begin{array}{l}\mathrm{s}[\mathrm{s}] \\
\mathrm{z}[\mathrm{z}]\end{array}$ & $\int[j]$ & & & $\mathrm{f}[\mathrm{h}]$ \\
\hline Nasal & $\mathrm{m}[\mathrm{m}]$ & & $\mathrm{n}[\mathrm{n}]$ & & & {$[\mathrm{y}]$} & \\
\hline Rhotic & & & $\mathrm{r}[\mathrm{x}]$ & & & & \\
\hline Lateral & & & $1[1 \mathrm{t}]$ & & & & \\
\hline Semi-vowel & $v[\mathrm{v} \mathrm{w}]$ & & $\mathrm{j}[3]$ & & & & \\
\hline
\end{tabular}

\section{References}

Afsar, A., \& Kamran, U. (2011). Comparing Consonantal Phonemes of Pakistani Standard English with British Standard English. Kashmir Journal of Language Research, 14(1), 29-48.

Ali, A. (1993). English in South Asia: A Historical Perspective. In Baumgardener (Ed.), The English Language in Pakistan (pp. 3-12). Karachi: Oxford University Press.

Asrani, U. A. (1964). What shall we do about English? Ahmedabad: Navajivan Publishing House.

Backley, P. (2011). An introduction to element theory. Edinburgh: Edinburgh University Press.

Best, C. T. (1995). A direct realist view of cross-language speech perception. In W. Strange (Ed.), Speech perception and linguistic experience: Issues in cross-language research (pp. 171-204). Timonium MD: York Press.

Best, C. T., \& Tyler, M. D. (2007). Nonnative and second-language speech perception: Commonalities and complementarities. In O. S. Bohn \& M. J. Munro (Eds.), Language experience in second language speech learning: In honor of James Emile Flege (pp. 13-34). Amsterdam: J. Benjamins.

Boersma, P., \& Weenink, D. (2012). Praat: doing phonetics by computer. Retrieved from http://www.fon.hum.uva.nl/praat/

Brown, C. A. (1998). The role of the L1 grammar in the L2 acquisition of segmental structure. Second Language Research, 14(2), 136-193. https://doi.org/10.1191/026765898669508401

Brown, C. A. (2000). The interrelation between speech perception and phonological acquisition from infant to adult. In J. Archibald (Ed.), Second language acquisition and linguistic theory (pp. 4-63). Malden Mass: Blackwell.

Chomsky, N., \& Halle, M. (1968). The sound pattern of English. New York: Harper and Row. 
Clements, G. N. (1985). The geomtry of phonological features. Phonology Yearbok, 2, 225-252. https://doi.org/10.1017/S0952675700000440

Clements, G. N., \& Hume, E. V. (1995). The internal organization of speech sounds. In J. Goldsmith (Ed.), A handbook of phonological theory, 245-306. Oxford: Blackwell.

Davenport, M., \& Hannahs, S. J. (2010). Introducing Phonetics and Phonology. London: Hodder Education.

Docherty, G. J. (1992). The timing of voicing in British English obstruents. Berlin: Foris publications. https://doi.org/10.1515/9783110872637

Elfenbein, J. (1997). Balochi Phonology. In A. S. Kaye (Ed.), Phonologies of Asia and Africa, 2, 761-776. Indiana: Eisenbrauns.

Elfenbein, J. (1997). Pashto Phonology. In A. S. Kaye (Ed.), Phonologies of Asia and Africa, 2, 733-759. Indiana: Eisenbrauns.

Flege, J. E. (1993). Production and perception of a novel, second-language phonetic contrast. Journal of the Acoustical Society of America, 93(3), 1589-1608. https://doi.org/10.1121/1.406818

Flege, J. E. (1995). Second language speech learning: Theory, findings, and problems. In W. Strange (Ed.), Speech perception and linguistic experience: Issues in cross-language research (pp. 233-277). New York: Timonium, MD.

Flege, J. E., \& Eefting, W. (1988). Imitation of a VOT continuum by native speakers of English and Spanish: Evidence for phonetic category formation. Journal of the Acoustical Society of America, 83(2), 729-740. https://doi.org/10.1121/1.396115

Flege, J. E., \& Port, R. (1981). Cross-language phonetic interference: Arabic to English. Language \& Speech, 24(2), 125-146.

Hamann, S. (2003). The phonetics and phonology of retroflexes. Utrecht: Utrecht University

Hamann, S. (2005). The diachronic emergence of retroflex segments in three languages. Link, 15, 29-48.

Hamann, S. (2011). Phonetics-phonology interface. In N. C. Kula, B. Botma, \& K. Nasukawa (Eds.), The continuum companion to phonology (pp. 202-224). London: Continuum international publishing group.

Harris, J. (1994). English sound structure. Oxford: Blackwell.

Hayes-Harb, R., Nicol, J., \& Barker, J. (2010). Learning the phonological forms of new words: effects of orthographic and auditory input. Language \& Speech, 53(3), 367-381. https://doi.org/10.1177/0023830910371460

Honeybone, P. (2005). Diachronic evidence in segmental phonology: The case of laryngeal specifications. Berlin: Mouton de Gruyter.

Iverson, G. K., \& Salmons, J. C. (1995). Aspiration and laryngeal representation in Germanic. Phonology, 12(3), 369-396. https://doi.org/10.1017/S0952675700002566

Iverson, P., \& Kuhl, P. K. (1995). Mapping the perceptual magnet effect for speech using signal detection theory and multidimensional scaling. Journal of the Acoustical Society of America, 97(1), 553-562. https://doi.org/10.1121/1.412280

Kachru, B. B. (1992). The Other Tongue: English Across Cultures. Urbana: University of Illinois Press.

Khubchandani, L. M. (2007). Sindhi. In G. Cordona \& D. Jain (Eds.), The Indo Aryan Languages (pp. 683-721). New York: Routledge.

Koul, N. O. (2007). Kashmiri. In G. Cordona \& D. Jain (Eds.), The Indo Aryan Language (pp. 991-1051). New York: Routledge.

Kuhl, P. K. (1994). Learning and representation in speech and language. Current Opinion in Neurobiology, 4(6), 812-822. https://doi.org/10.1016/0959-4388(94)90128-7

Kuhl, P. K., Conboy, B. T., Coffey-Corina, S., Padden, D., Rivera-Gaxiola, M., \& Nelson, T. (2008). Phonetic learning as a pathway to language: new data and native language magnet theory expanded (NLM-e). Philosophical Transactions of the Royal Society of Biological Science, 363, 979-1000. https://doi.org/10.1098/rstb.2007.2154

LaCharite, D., \& Paradis, C. (2005). Category Preservation and Proximity versus Phonetic Approximation in Loanword Adaptation. Linguistic Inquiry, 36(2), 223-258. https://doi.org/10.1162/0024389053710666 
Ladefoged, P., \& Maddieson, I. (1996). The sounds of the world's languages. Oxford: Blackwell.

Larson-Hall, J. (2016). A guide to doing statistics in second language acquisition. London: Routlege

Lisker, L., \& Abramson, A. (1964). A cross-language study of voicing in initial stops: acoustical measurements. Word, 20(3), 384-422. https://doi.org/10.1080/00437956.1964.11659830

Mahboob, A., \& Ahmar, N. H. (2004). Pakistani English: Phonology. In E. W. Schneider (Ed.), A Handbook of Varieties of English: A Multimedia Reference Tool (pp. 1003-1015). Berlin: Mouton de Gruyter.

McCarthy, J. (1988). Feature geometry and dependency: a review. Phonetica, 43, 84-108. https://doi.org/10.1159/000261820

Rahman, T. (1991). Pakistani English: some phonological and phonetic features. World Englishes, 10(1), 83-95. https://doi.org/10.1111/j.1467-971X.1991.tb00139.x

Rahman, T. (1996). Language and politics in Pakistan. Karachi: Oxford University Press.

Rahman, T. (2011). From Hindi to Urdu: A social and political history. Karachi, Pakistan: Oxford University Press.

Rice, K., \& Avery, P. (1993). Segmental complexity and the structure of inventories. Toronto Working Papers in Linguistics, 12(2), 131-153.

Roca, I., \& Johnson, W. (2007). A course in phonology. Oxford: Blackwell.

Sagey, E. (1986). The representation of features and relations in non-linear phonology. Massachusetts: Massachusetts Institute of Technology.

Schmidt, R. L. (2007). Urdu. In G. Cordona \& D. Jain (Eds.), The Indo Aryan Languages (pp. 387-415). New York: Routledge.

Shackle, C. (1976). The Siraiki language of central Pakistan: A reference grammar. London: University of London School of Oriental and African Studies.

Shackle, C. (2007). Punjabi. In G. Cordona \& D. Jain (Eds.), The Indo Aryan Language (pp. 561-621). New York: Routledge.

Shimizu, K. (2011). Study on VOT of initial stops in English produced by Korean, Thai and Chinese speakers as L2 learners. Paper presented at the ICPhS XVII, Hong Kong.

Simon, E. (2009). Acquiring a new second language contrast: an analysis of the English laryngeal system of first language Dutch speakers. Second Language Research, 25(3), 377-408. https://doi.org/10.1177/0267658309104580

Simon, E. (2011). Laryngeal stop systems in contact: Connecting present-day acquisition findings and historical contact hypotheses. Diachronica, 28(2), 225-254. https://doi.org/10.1075/dia.28.2.03sim

Sisson, R. R. (1971). The description and comparison of stress in South British English and Hindi. Linguistics: An International Review, 17, 35-60.

Spencer, A. (1996). Phonology: theory and description. Oxford: Blackwell.

Syed, N. A. (2011). Perception and production of consonants of English by Pashto speakers. The Journal of Humanities and Social Sciences, XIX(1), 119-146.

Syed, N. A. (2012). Perception and production of English [d] by Pakistani L2 learners. Essex Graduate Students Papers in Language and Linguistics, University of Essex, 13, 134-157.

Syed, N. A. (2013). Acquisition of [r] by Pakistani learners. In L. Spreafico \& A. Vietti (Eds.), Rhotics. New data and perspectives (pp. 41-56). Bozen-Bolzano: Bolzano-University press.

Syed, N. A. (2013). Acquisition of a new sound without separate category formation. In B. Surany (Ed.), Proceedings of the Second Central European Conference in Linguistics for Postgraduate Students (pp. 230-245). Pilicscaba, Budapest: Peter Pazmany Catholic University Hungary.

Syed, N. A. (2013). Acquisition of alveo-palatal [3] by Pakistani learners of English. Journal of Social Sciences and Interdisciplinary Researc, 2(1), 39-50.

Syed, N. A. (2013). Acquisition of dental fricatives by adult Pakistani learners. Newcastle Working Papers in Linguistics, 19(2), 64-73.

Syed, N. A. (2013). Learning is a function of perceived phonetic distance between two sounds. Kashmir Journal 
of Language Research, 16(1), 115-139.

Syed, N. A. (2013). Voice Onset Time (VOT) for Voiceless Plosives in Pashto (L1) and English (L2). Journal of Humanities and Social Sciences, XXI(3), 79-94.

Syed, N. A. (2013). Voice onset time for plosives in Saraiki: Implications for the acquisition of English aspiration contrast. EFL Annual Research Journal, 14, 1-15.

Syed, N. A. (2014). Influence of L1 laryngeal contrast in acquisition of allophonic variance in English plosives. Balochistan Journal of Linguistic, 1, 45-65.

Syed, N. A. (2014). Why Pakistani learners cannot acquire English voiced stops? Journal of Research in Social Sciences, 1(1), 19-30.

Syed, N. A. (2015). The Role of Teacher in Second Language Learning. The Journal of Linguistic Inquiry, 13(1), 71-91.

Usmani, M. A. H. (1965). A study of the teaching of English as a foreign language in the secondary schools of the Peshawar region, West Pakistan. Texas: Texas Technological College.

Wester, F., Gilbers, D., \& Lowie, W. (2007). Substitution of dental fricatives in English by Dutch L2 speakers. Language Science, 29(2-3), 477-491. https://doi.org/10.1016/j.langsci.2006.12.029

\section{Notes}

Note 1. Although Pashto language does not have aspiration contrast at phonemic level, acoustic analysis confirms that Pashto speakers also do not strictly maintain aspiration contrast in English voiceless stops (Syed 2013f).

Note 2. Rahman ascribes Pakistani speakers' failure to maintain aspiration contrast to wider differences between VOTs of Urdu and English aspirated stops. For details see Rahman (1991).

Note 3. In Urdu, the same fricative occurs in Persian loanwords. Only those Pakistanis whose mother tongue is Urdu, are expected to produce it as an obstruent fricative.

Note 4. However, we have not yet confirmed this phenomenon in English speech of speakers of other Pakistani languages. Therefore, this generalization is only true about those Pakistani speakers who speak Saraiki as L1.

Note 5. The generalizations about $/ \mathrm{h} /$ developed in this sub-section are not valid for those PakE speakers who speak Pashto and Balochi as their L1s because it we do not have empirical evidence whether $/ \mathrm{h} /$ is voiceless or voiced in these languages.

\section{Copyrights}

Copyright for this article is retained by the author(s), with first publication rights granted to the journal.

This is an open-access article distributed under the terms and conditions of the Creative Commons Attribution license (http://creativecommons.org/licenses/by/4.0/). 